\title{
Unitization of petroleum fields in the Barents Sea: Towards a common understanding?
}

\author{
Daniel Fjærtoft, \\ Sigra Group
}

\author{
Arild Moe*, \\ Fridtjof Nansen Institute
}

Natalia Smirnova, Mining University, St. Petersburg

\section{Alexey Cherepovitsyn \\ Mining University, St. Petersburg}

\begin{abstract}
The expected discovery of petroleum fields that cross the new boundary between Russia and Norway in the Barents Sea could mean that both parties will lay claim to the same subsoil resources. The Treaty on Maritime Delimitation in the Barents Sea and the Arctic Ocean (Barents Treaty) prescribes that such fields should be developed as one unit, governed by a unitization agreement between the two governments and a joint operating agreement between license holders on the respective sides of the border. Norway has more than 40 years' experience from the unitization of cross-border fields in the North Sea with the United Kingdom. Russia's experience with crossboundary petroleum field development is limited to Kazakhstan in the Caspian Sea and onshore, where bilateral resource management has been governed by other principles and institutions. While the Barents Treaty text clearly reflects the Norwegian way of managing offshore fields, it does not preclude the Russian way of doing so. We find reason to believe that both parties will enter negotiations over a cross-boundary field in the Barents Sea believing their understanding reflects the true concept of unitization. Despite objective differences between Norwegian and Russian legislation and practice, there is evidence that the two nations have more in common than not in their underlying principles. Discussions are likely to arise regarding the practicalities of implementing field unitization, and arriving at a common understanding will probably require some time.
\end{abstract}

Keywords: Norway; Russia; oil; gas; cooperation; exploration; offshore; delimitation

Received: November 2017; Accepted: February 2017; Published: March 2018

^Correspondence to: arild.moe@fni.no

(C)2018 Daniel Fjærtoft et al. This is an Open Access article distributed under the terms of the Creative Commons Attribution-NonCommercial 4.0 International License (https://creativecommons.org/licenses/by-nc/4.0/), allowing third parties to share their work (copy, distribute, transmit) and to adapt it, under the condition that the authors are given credit, that the work is not used for commercial purposes, and that in the event of reuse or distribution, the terms of this license are made clear. 


\section{Introduction}

Russia and Norway started exploring for hydrocarbons in the Barents Sea around 1980. ${ }^{1}$ Claims for exclusive resource rights in a large area on the continental shelfsome 175,000 square kilometers-were put forward by both the Soviet Union and Norway in the late 1970s; and from the early 1980s both countries refrained from exploration activity in the disputed area, to avoid conflict. However, after almost forty years of negotiations, an agreement was finally reached in 2010, establishing a firm delimitation line and dividing the disputed area 50/50 between the two states. ${ }^{2}$ This allowed seismic surveys to start there in 2011.

The discovery of petroleum fields that cross the boundary between the two countries are expected. In such a case, both parties could lay claim to the same subsoil resources. ${ }^{3}$

The boundary agreement "Treaty between the Kingdom of Norway and the Russian Federation concerning Maritime Delimitation and Cooperation in the Barents Sea and the Arctic Ocean "4 (referred to as the Barents Treaty below) prescribes that such fields are to be developed as one unit, governed by a unitization agreement between the governments of Russia and Norway, and a joint operating agreement between license holders on the respective sides of the border.

The principal research question in this article is whether the two countries are likely to differ in their approaches and policies regarding implementation of the unitization provisions of the Treaty. We do not attempt to conduct a comprehensive or comparative legal analysis of the Barents Treaty in the context of international law, as this has been thoroughly discussed by Bankes, ${ }^{5}$ Henriksen and Ulfstein ${ }^{6}$ and others. The relationship between the Barents Treaty and Russian domestic legislation does, however, constitute a gap in the legal literature and is addressed in a companion article by Fodchenko. ${ }^{7}$

In this article, we are concerned with practice and policies: examining how Norway and Russia have approached and solved similar challenges elsewhere. Some policies have been codified in agreements and laws; other emanate from experience and tradition. Differences in experience should not be dismissed as inconsequential. ${ }^{8}$ Even though stakeholders realize that the situation ahead is fundamentally new, they remain influenced (consciously or subconsciously) by what they perceive as their most relevant past experience. The upshot is that rather than risk failure, the parties should investigate differences, in order to find ways to manage them before they become problematic. ${ }^{9}$

We focus on the overarching principles for trans-border petroleum development: How have Norway and Russia organized trans-border petroleum development in the past, what role has unitization played in the policies of the two countries and how is the concept understood. Special attention is given to the determination and apportionment of resources.

The article is structured in four parts:

a. An introduction to the concept of unitization

b. A study of relevant Norwegian experiences with the UK and other jurisdictions

c. A discussion of Russian approaches to cross-boundary discoveries 
d. A discussion on the Barents Treaty and the compatibility of Norwegian and Russian experiences, indicating potential sources of mutual misunderstanding.

\section{Unitization: Why and How}

In the absence of outside regulation, each party with claims to a common resource reservoir will rationally maximize its revenues by competitive drilling and aggressive reservoir drainage strategies - causing final resource distribution to deviate from initial ownership, and leading to reduced total reservoir recovery. ${ }^{10}$ For optimal resource recovery, a given deposit must be developed as one unit-in turn leading to the increasingly common practice of combining ownership rights to a shared reservoir through the process of unitization. Unitization may be defined as "the joint, coordinated operation of an oil or gas reservoir by all the owners of rights in the separate tracts overlying the reservoir or reservoirs." 11

\subsection{Domestic Unitization}

Unitization was pioneered in the USA, where many privately owned tracts tended to overlie oil reservoirs. An 1889 Pennsylvania court ruling had legalized the rule of capture: acknowledging that ownership to subsoil oil and gas shifted from the land under which it was originally located, to the land tract to which the resource had migrated following drilling on that land. ${ }^{12}$ Over the next 45 years, it was increasingly recognized that competing to capture these fluid resources led to over-drilling, aggressive drainage, and reservoir damage wasteful for individual resource owners as well as for society. This prompted several states to launch the Interstate Compact to Conserve Oil and Gas in $1935,{ }^{13}$ obliging signatories to pass legislation to avoid waste of oil and gas resources. The subsequent development of state-level "pooling legislation" obliged land owners to "pool" (unitize) their interest in petroleum development so acreage became of a size believed sufficient to avoid competing entities drilling for the same resource..$^{14}$ As such, these arrangements represented a predecessor to today's concept of unitization, which, due to a greater understanding of subsoil geology, focuses on uniting a specific deposit rather than landowner interests ex-ante..$^{15}$

Although unitization emerged in response to coordination challenges stemming from private ownership to subsoil resources, coordination challenges also arise in countries with state ownership of natural resources. Resource management policies which restrict each license area while encouraging large numbers of licensees make inter-license coordination of paramount importance to the state as the resource owner, regardless of licensees' ownership structures. ${ }^{16}$

\subsection{Cross-border Unitization}

A petroleum deposit straddling the border between two countries "can [technically] be exploited, wholly or in part, from the other side of the line." ${ }^{17}$ However, since unilateral development of such a deposit would imply that one party extracts resources 
initially in place in the other party's jurisdiction, thereby affecting this party's reservoir drainage opportunities, such an activity by one party would violate the other country's exclusive (resource) rights and thereby breach international law. ${ }^{18}$ To avoid such conflicts, the two countries must enter into an agreement on this accord before petroleum activity can legally commence. ${ }^{19}$

Such an agreement needs to account for the same technical and commercial issues that apply when a field is unitized within a single national jurisdiction. However, while national legislation often provides guidance on principles and procedures for reaching agreement as well as arbitration, international law is, according to Cameron, ${ }^{20}$ deficient here, leaving even the most basic arrangements subject to negotiation.

Weaver and Asmus ${ }^{21}$ examine the technicalities of unitization and its many forms across the world in significant, if not exhaustive, detail. Awambu ${ }^{22}$ points to the fact that by crossing national borders, field geology undermines the stability of the contractual framework under which licensees normally operate:

Firstly, a licensee's opportunity to exploit the resource rights it has negotiated with a host government is also constrained by legislation and policy in the adjacent jurisdiction.

Secondly, depending on negotiations between host governments and the apportioning of resources between licensees on either side of a border, the final stakes in a given field may be changed from what oil companies on both sides of the border had originally agreed.

Thirdly, the risk of delays increases, as both countries must approve any significant decisions. And, as it is widely assumed that governments are less affected than companies by the time-value of money and therefore the cost of delays, governments may be prone to prolong negotiations in order to increase national returns from the field.

These complications translate into increased risk for the companies involved.

\subsection{Sharing Resources, Revenues, and Costs}

As in any commercial joint venture (JV), the parties must agree on how to share costs as well as revenues. A crucial issue in cross-border discoveries is an exact determination of where resources belong. In itself a complicated process, this usually determines the division of costs and revenue between the parties.

However, resource determination is not necessarily established early on. The division of costs and revenues may therefore have to be decided according to expected resources on either side of the border. This division may be altered later, as more complete information on resources in place is acquired. This process, often referred to as redetermination, can be the subject of lengthy disputes (see the Statfjord case, below), involving disagreement on reservoir models and interpretation of data by the unitized parties and external arbiters.

In principle, there is no requirement that costs and revenues must be divided in proportion to the resources in place. Such a division is most common, but governments remain free to agree on whatever they wish here. 
For investors - oil companies engaged in exploration near the boundary-early agreement on principles is vital, to provide predictability in case a cross-boundary discovery is made. As agreements between governments tend to be elaborated only in response to practical necessity, early agreement may constitute a challenge. The less mature a bilateral relationship is in terms of joint petroleum development, the more uncertainty is likely to exist.

\section{Norway's Unitization Experience}

On the Norwegian continental shelf, 42 fields have been developed as units, of which five are cross-border with the United Kingdom: Frigg, Statfjord, Murchison, Blane and Enoch. ${ }^{23}$

Below we discuss the agreements and practical implementation surrounding the two largest fields, Frigg and Statfjord. In addition to relations with the UK, Norway has signed agreements with Sweden and Iceland and four agreements with Denmark pertaining to the border between Norway and Denmark, the Faroe Islands, Greenland and lastly between Svalbard and Greenland. These all presume unitization in the event of a discovery. In the absence of such, we will discuss them here no further, as our primary focus is on practical experience from field unitization.

Norway's agreement with Iceland is the only exception. This agreement introduces the concept of a joint development zone, which bears resemblance to Russia's arrangements with Kazakhstan (see more below). Establishment of a joint development zone was put forward by the Soviet side in negotiations with Norway on the delimitation of the continental shelf in the Barents Sea around 1990, ${ }^{24}$ and also proposed by Russian officials later. ${ }^{25}$

\subsection{UK Treaty}

The Norway-UK delimitation treaty was signed on March 10, 1965. ${ }^{26}$ As cross-border petroleum discoveries were anticipated, its Article 4 included a commitment to seek joint development of such resources. This stipulation was the first of its kind among international border treaties. ${ }^{27}$

If any single geological petroleum structure or petroleum field, or any single geological structure or field of any other mineral deposit, including sand or gravel, extends across the dividing line and the part of such structure or field which is situated on one side of the dividing line is exploitable, wholly or in part, from the other side of the dividing line, the Contracting Parties shall, in consultation with the licensees, if any, seek to reach agreement as to the manner in which the structure or field shall be most effectively exploited and the manner in which the proceeds deriving therefrom shall be apportioned. ${ }^{28}$

Although Article 4 did not explicitly prescribe the procedure, unitization has become the parties' preferred (and indeed only) choice for meeting the obligation to "seek to reach agreement" on how a cross-border petroleum deposit "shall be most effectively exploited." 


\subsection{Frigg Agreement}

When it was discovered in 1971, the Frigg field in the North Sea was the world's largest offshore gas field. Signed on May 10, 1976 and entering into force on July 22, $1977,{ }^{29}$ the Frigg Agreement became Norway's first unitization agreement. Its key principles have proven formative, not only for the unitization of Norwegian fields, but it has also provided important precedence for unitization negotiations internationally. It should be noted that Norway ${ }^{30}$ and the $\mathrm{UK}^{31}$ already had developed petroleum management systems with important similarities, notably the common practice of giving a license for a field to a group of companies rather than a single company. Each company in the group would have a share in the license and invest in development (and be rewarded when revenues are created) in the same proportion as its ownership in the license. Together the companies form a license or management committee. They control the work and approve the plans and budget of the operator, one of the shareholders in the license who carries out the actual work on the license on behalf of the license group.

To provide a descriptive definition of what a unitization agreement includes and a historical point of departure for the discussions to follow, the Frigg agreement's key principles are summarized in the box below.

Frigg Agreement: Main principles

- Development of the Frigg resources as one unit (Preamble and Article 1, para. 1)

- Apportionment of produced gas according to the initial distribution of resources on either side of the border (Article 3, para. 3)

- Prescriptions for when a government can request that a process be launched to reassess the initial distribution of resources (redetermination): at the time of first gas and every fourth year thereafter, as well as upon discovery of reservoirs communicating with the Frigg reservoir. (Article 3, para. 1)

- Historically incurred imbalances in production as measured by the (new) post-redetermination resource allocation to be corrected through time-limited adjustments in percentage shares of production until such imbalances are settled. (Article 3, para. 3)

- License holders shall be taxed in accordance with their "home" jurisdiction. (Article 9, para. 1)

- Each government has the right to demand that the license holders in its own and the other government's jurisdictions conclude a Unit Operating Agreement that must be approved by these governments. Any changes in the composition of license holders on either side of the border, as well as changes to the agreement, require approval from both governments. (Article 1, para. 2)

- The Unit Operating Agreement shall appoint one field operator. (Article 5) (Before unitization there is a license group with one operator on each side of the border. After unitization there will only be one operator.) An obligation to allow for free flow of personnel and materials over the border, including equal access for inspectors from either side, unless security concerns require otherwise. (Article 6, para. 1)

An obligation to align health, security and environmental (HSE) standards and procedures, to the extent possible, as well as the possibility for each country to shut down production immediately due to HSE concerns at any time. (Article 7, para. 1)

- A requirement to agree on the equipment for measuring gas and liquids quantities as well as the methodology for quantification. (Article 22, para. 1)

Conflict resolution procedures: potential conflicts over the size of the deposit or apportionment of resources should first be subject to negotiations in a joint commission (consisting of three members from each state) and/or between the countries' respective governments. If no agreement is reached, the conflict is to be resolved by means of arbitration, with one judge from each of the countries and a third judge from a third-party country. (Article 28). 
As noted by Smith, the primary responsibility for exploiting the field is left to the licensees. ${ }^{32}$

\subsection{Frigg: Redetermination as a Way Forward}

After the Norwegian company Norsk Hydro and the Norwegian government exercised post-discovery options to increase their stake, the Norwegian license had the following stakeholder composition: Elf (operator, 27.61 percent), Norsk Hydro (32.87 percent), Total Marine (20.71 percent), Aquitaine (13.81 percent), and Statoil (5 percent). Licensees on the British side were Total Marine (operator, 33.33 percent), Elf (44.45 percent), and Aquitaine (22.22 percent). This stakeholder composition proved important in the ensuing negotiations on resource distribution. The French companies were perceived by the Norwegian side to be in collusion and biased in favor of the UK because their shares were larger on the UK license side of the border. This impaired trust within the partnership and more importantly between the operator and the Norwegian majority stakeholder. ${ }^{33}$

The principles established by the Frigg Agreement formed the basis from which all of Norway's international as well as national unitization agreements have evolved. However, what has become common practice today was not a self-evident outcome at the time of negotiations. The 1965 Norway UK delimitation treaty did not oblige the parties to reach, only to seek, an agreement. At the time, there was no established precedent for forcing unitization upon the licensees; ${ }^{34}$ the governments participated from the sidelines when negotiations started between the companies to reach an agreement, which would later be submitted to their respective governments for formal approval.

According to a historical account of the negotiation process, ${ }^{35}$ two issues proved especially tricky. Firstly, there was great uncertainty over the size of the gas resources, as well as allocation between the Norwegian and British sectors. Initial estimates indicated that as much as 50 percent of the resources were located in the British sector, but Norway believed its share to be much larger. The second issue concerned the resource evacuation plan. Norwegian petroleum law required that Norwegian resources be landed and processed in Norway; on the British side, however, the British Gas Council was entitled to buy all gas from the British continental shelf. The French operators argued for a single pipeline to the UK, whereas the Norwegian authorities argued that the Norwegian share of the gas should be landed in Norway.

Both issues stalled field development. At one point, in June 1972, Total even threatened to start development unilaterally, with or without an agreement. Some headway was achieved when Norwegian authorities accepted landing the gas in Aberdeen and abandoned the idea of parallel evacuation infrastructure to Norway-but in the meantime, resource uncertainty had only increased. In an apparent effort to reach some form of arrangement, Elf proposed that the parties hire an external consultant to determine resource allocation. This served as the foundation for the Frigg Field Main Agreement, a principle agreement between the license groups on each side of the border, signed in July $1973 .{ }^{36}$ The field should be developed as one unit, and the 
participants' share should be conditioned by original ownership and final resource allocation as determined by the consultant. Thus, the final decision on resource allocation was postponed. Initially the consultancy firm, DeGolyer and MacNaughton, was to conclude on resource allocation by November 1974, but after preliminary results that brought Norway's share down toward 50 percent were presented to the Norwegian authorities, Statoil and Norsk Hydro persuaded the consultant to wait until two more wells had been drilled. ${ }^{37}$ Thereby final decision on resource allocation was further postponed; it was still undetermined when Norway and the UK signed the Frigg Unitization Agreement in 1976.

The Frigg Agreement not only established unitization as the principle for shared fields, it also introduced the redetermination mechanism, whereby unitization and field development could proceed, even in the absence of a final agreement on resource allocation, size of reserves, as well as field boundaries. This mechanism has since proven vital in facilitating investments under conditions of uncertainty over resources in place and their allocation.

\subsection{Statfjord Agreement}

Only two years after the Frigg Agreement, two new unitization agreements were signed, for the fields Statfjord ${ }^{38}$ and Murchison. ${ }^{39}$ The Statfjord Agreement dwarfed the other two in economic importance, as it concerned one of the largest oil fields in the North Sea, with total initial reserves of roughly 5 billion barrels of oil equivalent. ${ }^{40}$

In content, the Statfjord Agreement is almost identical to the Frigg Agreement, but with important amendments. The procedures for timing redetermination are further elaborated, including a provision for redetermination after drilling of the last well of the agreed field development plan, as well as some other timeline amendments. In relation to infrastructure, it was agreed to transfer oil directly to tankers for transportation to world markets, thereby avoiding discussions on the location of onshore oil terminals.

Although the Statfjord Agreement was dated June 1, 1979, it had, in fact, been effective since 1976 on a provisional basis. ${ }^{41}$ Moreover, by 2009, the Agreement had been amended more than 20 times to account for conditions not foreseen in 1976 .

It was agreed that field operations would be conducted according to Norwegian law, regulations and requirements, as the platforms and other infrastructure were situated on the Norwegian side of the border. Voting rules required 70 percent of the licensees to reach a binding decision, with a few exceptions. Most importantly, re-apportioning reserves and permitting the use of Statfjord's facilities by other petroleum fields would require unanimous approval, although each party had the right to raise these issues. ${ }^{42}$ Both proved to be matters of serious and recurring discussions.

\subsection{Redetermination as a Recurring Headache}

Redetermination has received significant attention in the unitization agreements between Norway and the UK. It started as a consequence of a compromise (Frigg), evolved into procedures fixed in the bilateral unitization agreement by the two 


\section{Daniel Fjertoft et al.}

Governments (Statfjord), and, since the 2005 framework agreement, has become a prerogative of the companies involved.

To understand the complications that may arise from resource negotiations, one must bear in mind that total reserves as well as allocation between sectors cannot be determined accurately—only estimated. Nor is such estimation a straightforward exercise; the results depend on the choice of assumptions, methodology, and other aspects. However, agreeing on a given estimate may be even harder, as shown by the Statfjord redeterminations. The account of one of the participants in the process from the Norwegian side, Håkon Lavik, is rendered in abbreviated form and authors' wording in the remainder of this section. ${ }^{43}$

The ownership of Statfjord Unit was redetermined many times after the initial ownership split had been set at 88.88 percent to Norway and 11.12 percent to the UK in 1976. Already at first oil in 1979, this was changed to 84.09 percent to Norway and 15.91 percent to the UK. This was, in fact, a significant change, given the size of the field; Lavik speculates that the Norwegian side agreed to terms it considered unreasonable in order to avoid postponing development, hoping it would have a chance to regain later what had been lost.

Even though the Norwegian side felt the UK already held an unfair share, the UK requested another redetermination in 1985, hoping to increase its own share further. However, it quickly became clear that Norway would benefit from redetermination; indeed, when the operator (Mobil) presented its recommendation, Norwegian ownership was set to increase, back to around 88 percent.

Prolonged disagreement ensued, in which neither side abided by the procedures stipulated in the unitization agreement, and there were mutual accusations of foul play. The UK side repeatedly sought to undermine estimation results by requesting new data; the Norwegian side reacted by delaying its compliance with the British requests. Sixty meetings were held between 1985 and 1989, without bringing the parties any closer to a solution.

In 1989, the Energy Minister of the UK called for a political solution to the dispute, a solution that would in fact violate the unitization agreement, which prescribed arbitration. However, the Norwegian government was reluctant to launch arbitration processes against the UK, and so the Minister's request was simply ignored. Instead, the parties decided to start anew in 1989, and silently forget about the 1985 process.

As before, the conclusion reached by the operator involved increasing the Norwegian share, which was rejected by the British. The license holders then recommended commissioning an expert review by DeGolyer and MacNaughton, which in 1991 ruled to increase ownership by 1.15 percentage points in favor of Norway. This changed the ownership distribution to 14.76 percent and 85.24 percent for the British and Norwegian sides, respectively.

Since the unitization agreement authorized redetermination every four years, the Statfjord partners had to consider launching a new process only two years later, in 1993. However, there was not enough time to collect new data to substantiate new 
estimates. Moreover, according to the unitization agreement, redetermination could continue at four-year intervals until production ended-and it was becoming clear that in case of further rulings in favor of Norway, the British side would not have enough reserves left to compensate Norway for earlier British excess earnings. Against this background, it was decided to have one final redetermination starting in 1995.

First, the parties had to circumvent the unitization agreement, so that redetermination could be launched before another four years had passed, when it might be too late for the British to pay back in oil. As before, the parties failed to reach agreement, and called for an expert verdict. However, the parties could not agree on an expert, so, in line with the procedures for expert appointment, the decision came to involve drawing lots between the candidates from the Norwegian and the British side in the operating committee, which the Norwegian license holders subsequently won. Thereupon the UK ministry exercised its right to veto the appointment of the independent expert, sending the process into a stalemate.

Lavik argues that the British were still bent on regaining what had been lost in the 1989 process; and that, realizing this, the Norwegians eventually conceded that agreement would have to be reached outside the logic of geological analysis.

Prolonged negotiations followed; the Norwegian partners even tried, unsuccessfully, to placate the British by offering a symbolic increase in ownership. Finally, in 1997, the parties agreed that there would be no changes in the ownership structure, effectively sidestepping the procedures outlined in the unitization agreement. However, it was necessary to get UK authorities onboard. The oil companies on the UK side were granted a postponement in paying back oil which they had disproportionately received, thus gaining a net present value advantage at a time when they had other significant investments in other fields on the UK shelf.

The UK Department of Trade and Industries and the Norwegian Ministry of Petroleum and Energy finally accepted this arrangement in 1998, granting coordinated approvals of the joint operating agreement. The ownership shares remained at 85.47 percent for the Norwegian side and 14.53 percent for the British. By 2017, oil production from the field had fallen to a fraction of what it was at its peak in the late 1980s and early 1990s. Output of gas and natural gas liquids was growing, however, because of new investment in the field. ${ }^{44}$

\subsection{Framework Agreement}

In expectation of further cross-border discoveries, the Norwegian and UK governments launched a joint working group in January 2002, the UK-Norway North Sea Co-operation Workgroup. The workgroup issued a report, "Unlocking Value Through Closer Relationships," ${ }^{45}$ that valued the potential benefit from efficiency improvements in cooperation on development of the North Sea petro-resources to USD 2 billion. The working group recommended entering into a framework agreement with accompanying guidelines, to ease future cooperation processes. It also identified some barriers to cooperation, including unaligned fiscal systems, the limited capacity 
of the connection to the St. Fergus gas terminal, and insufficient information on pipeline capacity.

In October 2003, the UK and Norwegian Energy Ministers issued a joint statement, two paragraphs long, under the heading "A win-win approach." The statement highlighted the scope for cooperation and the high trust between the parties, and outlined principles to be incorporated in the forthcoming framework agreement on cross-border cooperation. ${ }^{46}$

In April 2005, Norway and the UK agreed on a framework agreement that not only prescribed compulsory unitization of cross-border fields but also limited the room for intergovernmental field-by-field negotiations and improved coordination between regulatory authorities in both countries - in the hope of smoothing the forthcoming unitization processes. ${ }^{47}$ The procedure for redetermination was transferred from the unitization agreement to the operating agreement. The definition, measurement and evaluation of initial reserves were also to be agreed by the license holders in the operating agreement and subsequently approved by the respective authorities. Bankes defines the framework agreement as an international pioneer, which has since been followed by four international agreements covering areas where petroleum resources have yet to be found, one of which is the Barents Treaty. ${ }^{48}$

\subsection{Treaty With Iceland Opens Up for Simplified Resource Distribution}

On October 22, 1981, Norway and Iceland concluded a treaty on continental shelf delimitation. ${ }^{49}$ The agreement specified a certain area- "the cooperation area"where, upon commencement of petroleum activity by one party, the other party is entitled to participate with 25 percent. Bankes highlights the arrangement's uniqueness in establishing an Arctic joint development area and its non-legalistic approach to reaching an agreement and apparent concessions by Norway, based on notions of what might be accepted by the parties as 'a reasonable solution' rather than focusing on formal legal 'rights'. 50

On March 20, 2007, Icelandic authorities announced plans for issuing exploration and development licenses in the "cooperation area." The Icelandic and Norwegian governments then set about negotiating an agreement for cross-border petroleum field development, which was signed on November 3, 2008. ${ }^{51}$ According to this agreement, field development cannot commence before a unitization agreement has been concluded.

On January 4, 2013, Petoro, the Norwegian state-owned company managing the Norwegian state's direct participation in licenses, signed an agreement on participating in the second licensing round in Iceland with 25 percent ownership interest in two licenses. ${ }^{52}$ In view of the need to agree on a budget and a timeline for seismic operations, it "could take some time" before exploration drilling could commence. ${ }^{53}$ On November 26, 2013, Petoro entered into a third license in Iceland together with Chinese CNOOC International and Icelandic Eykon Energy. ${ }^{54}$ By 2016, it was estimated that drilling could commence between 2022 and 2026.55 


\subsection{Lessons Learned from Norway's Delimitation and Unitization Agreements}

Summing up the preceding sections, the following insights stand out as particularly relevant before embarking on an assessment of Russia's experience:

1. Median line-based delimitation and unitization agreements have been Norway's preferred tool for managing cross-border fields.

2. Redetermination has been an important mechanism to avoid negotiation stalemate and move forward in spite of resource uncertainty.

3. On the other hand, redetermination has also had the potential to instate a situation of perpetual negotiations draining management resources and creating uncertainty about final outcomes. Redetermination processes are also very expensive, costing several hundred million Norwegian kroner each time.

4. Notwithstanding close historical ties, a similar institutional environment and licensee composition, the scope for disagreement and protracted negotiating has been significant.

5. The choice of infrastructure and marketing solutions (e.g. gas pipelines for Frigg) and allocation of common infrastructure (e.g. Statfjord-Brent vs. timing of production from Norwegian satellites) have also proven to be subjects of tough debate. While agreements have evolved in order to efficiently handle the tricky resource distribution exercise, infrastructure issues remain without procedural guidance.

\section{Russia's Approach to Cross-boundary Discoveries}

Russia has far more experience in the petroleum industry than Norway, but this experience derives overwhelmingly from onshore activities.

During the Soviet period, petroleum exploration and extraction were conducted by territorially based state-owned entities. With any discovery, the borders of the field were defined and the field was subsequently registered in the state inventory. These already-defined fields served as the basis for the post-Soviet licenses, given to the oil companies established on the basis of the former state production associations. Overlapping or conflicting claims to hydrocarbons in these licenses have been rare. However, such claims have emerged when resources in a newly awarded license area extend into a neighboring license. A solution has been for one license owner to take over the other. Licenses as such cannot readily be sold, but companies can. Therefore a common procedure is to form a company for each license sought. ${ }^{56}$ An alternative is to form a joint venture company for development, without any strict delineation of the resource base. In either case, the need for strict delineation of the resource base is avoided, and the principle of awarding a license to one company is preserved.

Because of their impact on regional tax revenues, there have been disputes between federation subjects in cases involving hydrocarbon discoveries that cross administrative borders. However, a 2010 change in the taxation law transferred 100 percent 
of the minerals tax to the federal budget. ${ }^{57}$ Much of this tax income gets redistributed to the regional level, but according to other criteria than the actual location of resources. Remaining special taxes are paid where the larger part of the petroleum deposit is located. Since 2004, licenses for exploration and development are issued solely by the federal authorities. ${ }^{58}$ These developments have subdued disputes over trans-regional resources.

The need to find an arrangement in case of international trans-border discoveries became evident in the aftermath of the breakup of the Soviet Union. An agreement on delimitation of the exclusive economic zone and continental shelf in the Baltic Sea was signed with Lithuania in $1997 .{ }^{59}$ However, it merely declared that the parties would seek to reach agreement in accordance with international laws and recognized principles in the case of a cross-border field; and that the right of each party to resources on its continental shelf should be respected. That agreement failed to establish specific mechanisms for cooperation in the development of transboundary fields.

In 1998, a delimitation agreement with Kazakhstan was signed, based on the principle of a modified median line. ${ }^{60}$ As observed by Smith and Ashley Roach, economic considerations were important to both states. ${ }^{61}$ However, unitization was not mentioned explicitly. The agreement only stated that the parties would apportion resources in cross-border fields according to "established international practice." The delimitation line itself was not defined. Until such time, companies that conducted exploration activities would be considered representatives of the parties; if fields or prospects were identified, these companies would have priority claim to licenses, but would also be obligated to involve a representative from the other party.

However, other solutions to developing cross-boundary deposits were also put forward. In 1998, Ulianov and Diachkova described the background for and implementation of unitization schemes internationally, and argued for their relevance both in relation to petroleum fields crossing license boundaries as well as borders between federation subjects or international borders. Their work was initiated by the Ministry of Fuel and Energy. This shows that at a relatively early stage the concept and use of unitization was known, at least in parts of the Russian petroleum management bureaucracy.

\subsection{Practical Experience}

The delimitation line between Russia and Kazakhstan remained without fixed coordinates until 2002, when the two countries agreed on a protocol to their delimitation agreement, determining ownership and participation rights to two structures and one field. ${ }^{62}$

Even though unitization had not become a legal term in Russia, the main purpose of unitization had become a key concern, as the protocol prescribed that each field or structure would be developed as one unit. Russia would have sovereign resource rights and development would be under Russian legislation on the Tsentralnaya structure and the Khvalynskoe field, whereas Kazakhstan would have such rights on 
the Kurmangazy (Kulalinskaya) structure in the northernmost part of the Caspian. For each structure or field, a joint project was envisaged, with each Party holding 50 per cent as a point of departure. ${ }^{63}$

Thus, costs and resources would not be split in proportion to the distribution of resources on either side of the border, but according to the shares in projects, which were, rather schematically, divided fifty/fifty. However, the Party not holding the resource rights would have the option to take a smaller share if it wanted to.

The set-up was simple, not requiring meticulous assessments and apportionment of the resource base. The rules on organization of activities were short on detail, beyond stating that it could be any form of joint activity, but referred to as an enterprise. ${ }^{64}$

In the years that followed, obstacles to development did not emanate from the bilateral protocol, however, but from internal Russian policies. In 2003, a joint venture company, TsentrKaspneftegaz, was established to explore the Tsentralnaya structure. Lukoil and Gazprom held 25 per cent each and Kazmunaigaz of Kazakhstan 50 percent. ${ }^{65}$ In 2008 a discovery was made by the joint venture, but by 2009 Lukoil as a private Russian company had been banned from new offshore licenses, and the license renewal process (from exploration to development license) stalled. Only in 2016, after the prohibition on private companies was softened, was the license renewed, allowing a new joint venture between the same companies with the same shares - Neftegazovaya kompaniya Tsentralnaya. ${ }^{66}$

In 2005, another joint venture company was created for development of the Khvalinskoe structure - Kaspiyskaya neftegazovaya kompaniya, owned fifty-fifty by Kazmunaigaz and Lukoil. In 2009, the Kazakh company sold 25 percent to Total and GdF Suez. ${ }^{67}$ Once again, internal Russian regulations gave rise to complications, as the project was not given permission to export the gas, only supply it to domestic markets, because of Gazprom's export monopoly. ${ }^{68}$ It seems that development will continue to be stalled until an arrangement with Gazprom for export to China is found. ${ }^{69}$

An attempt at joint development was also made in connection with the onshore Imashevskoe field, discovered in 1985 on what was to become the Russian-Kazakh land border. ${ }^{70}$ In 2002, Gazprom and Kazmunaigaz formed $\otimes$ 50-50 joint venture company, KazRosGaz, which produced the first gas from Imashevskoe in 2007, according to company sources. ${ }^{71}$ The situation remained unsettled because even though Russia and Kazakhstan had agreed in 2013 to develop the field, a development license could not be issued, reportedly because of conflicting and insufficient legal provisions in the two countries..$^{72}$ In 2016, the Russian Ministry of Natural Resources found a temporary solution: it concluded that a license could be issued to the JV for geological work and exploration. However, when an auction for the license was to be organized, no company expressed interest. ${ }^{73}$

Even though the protocol between Russia and Kazakhstan seemingly opened for various forms of cooperation, the practical arrangements for all projects with Kazakhstan where Russia has the resource rights reflect the modus operandi in Russia when fields cross boundaries, namely the establishment of joint venture companies. 
But in the case of the Kurmangazy structure, which is under Kazakh jurisdiction, the parties agreed to let a Kazakh company take care of the practical work - as an operator. ${ }^{74}$

\subsection{Development of Principles}

Despite the dominance of the joint development approach and simplified apportionment of resources in Russian practice, Russian authorities have taken steps to develop more sophisticated schemes for the unitization of trans-border fields and fields crossing domestic administrative or license boundaries. Thus, in 2007, the Ministry of Natural Resources ordered the State Commission for Mineral Reserves (GKZ) of the Federal Subsoil Management Agency to produce a set of "Recommendations on assessment of reserves in adjoining and trans-boundary deposits", which were subsequently approved for use by the Ministry. ${ }^{75}$ It was still an operative document as of 2017. The Recommendations contain a clause stating that the document does not consider borders dividing fields on Russia's continental shelf "which fall under the jurisdiction of the international law of the sea". Given the general nature of the Recommendations, this sounds more like a formality than any real limitation on their potential applicability. They deserve attention as the only official document, to the knowledge of the authors of this article, that discusses unitization in some detail. The content is wider than the title of the document suggests.

The Recommendations explicitly take the principle of unitization "as used in world practice" as their point of departure (paragraph 5). Unitization is briefly defined as "consolidation [obyedinenie] of resource users for joint use of resources" (paragraph 5), but it is also stated that the purpose of a unitization agreement is to establish a unified accounting of costs and revenues with "subsequent division of these incomes and expenditures proportionally to the reserves belonging to each of the resource users" (paragraph 7). The document details a process for the determination of reserves. It is recognized that differences in tax regimes may influence the amount of recoverable resources on either side of the border, and that governments involved may agree to establish a single tax regime for the whole field (paragraph 30). Parties should agree to periodical redetermination of resources in the event of new data (paragraph 26).

Thus, the major purpose and principle of unitization is understood in the same way as in the various Norwegian agreements. However, these GKZ recommendations differ considerably from Norwegian practice when it comes to organization of activities. The document states that " $\ldots$ all parts of the field should be developed on the basis of a unified technological scheme, a unified plan for development" (paragraph 7), but does not spell out who is actually going to do this. For joint assessment of reserves, the parties should appoint an external company to conduct the resource assessment (paragraph 42), but the results are not binding (paragraph 44). Resource assessment by a third party as the default approach differs from the Norwegian practice where resource assessments are conducted by the license committee, led by the license operator. ${ }^{76}$ 
The recommendations also propose the establishment of a special body "for coordination of work and operative solution of problems emerging" (paragraph 43). Such a body could be led by one of the two parties on a rotation basis. "This special body (company) must be delegated sufficient authority to manage all processes relating to resource assessments and reporting to the government agencies." It is unclear exactly how broad a scope is intended, but such an organization would appear to have responsibility for the duties performed by a license committee in Norway, as well as functions performed by the field development operator. In a Norwegian context, licenses on each side of the border would be represented by the respective license operator; and establishing any joint organization would be considered premature.

The GKZ recommendations are not a set of draft regulations for unitization; they are only proposals for the exploration phase, when resource allocations are still unknown. Yet they represent a fairly comprehensive set of principles. Nevertheless, it is worth noting that they have not been further elaborated, whether in general regulations for trans-boundary resource development or in the specific agreements negotiated with Kazakhstan since 2007.

\section{The Norwegian-Russian Barents Treaty}

\subsection{Main Elements}

The "Treaty between the Kingdom of Norway and the Russian Federation concerning Maritime Delimitation and Cooperation in the Barents Sea and the Arctic Ocean" was signed in 2010 and entered into force in 2011. Its provisions concerning cross-border fields have many similarities with the 1965 Norway-UK Treaty and the 2005 Norway-UK Framework Agreement, but with a stronger commitment to unitize. Such a commitment was already established in a 2007 agreement between Norway and Russia on a boundary line close to the shore in the Varanger Fjord, but in less detail. ${ }^{77}$

According to the Barents Treaty, the parties to the Treaty, Russia and Norway, are required to enter into a unitization agreement. It is further specified that such an agreement is to involve the development of a cross-boundary field as one unit, and that the resources are to be divided according to their location: “...agreement on the exploitation of the hydrocarbon deposit as a unit, including its apportionment between the Parties, shall be reached at the request of one of the Parties." This crucial latter requirement differs from the approach in the arrangements Russia has concluded with Kazakhstan, but is in line with the recommendations from the GKZ.

Some of the elements previously covered in unitization agreements are elevated to treaty level. This resembles the 2005 Norway-UK Framework Agreement, as it clarifies some principle issues prior to discovery, such as redetermination preconditions 
and arbitration procedures, as well as a project management model with one operator and a distribution of shares in accordance with resources, while leaving other matters, like specific reservoir assessment methodology and decision making procedures, to be negotiated later.

Annex II, which forms an integral part of the 2010 Treaty, provides guidelines for the unitization process, but is not a unitization agreement in itself. The annex was allegedly also supposed to demonstrate in concrete terms what unitization would mean since many Russian stakeholders were expected to be unfamiliar with the concept.

According to Annex II of the Barents Treaty, a unitization agreement must include

- data on the reserves in place as well as methodology for determination of reserves

- distribution of the resource between the parties

- mutual access to geological data.

All these elements are similar to the 2007 GKZ recommendations. However, the obligation of license holders on each side to establish a "Joint Operating Agreement to regulate the exploitation of the transboundary hydrocarbon deposit" has no parallel in the GKZ recommendations. Such an agreement is a standard requirement in Norway, however, and regulates the relations between the various part-owners of a license and the operator. ${ }^{78}$

A procedure for redetermination is not mandatory, nor is it sufficient that one party should require it. Annex II, article 4 of the Treaty only includes the clause "the Parties may agree that the hydrocarbon deposit shall be reapportioned between them." Periodical redetermination was included in the GKZ recommendations. However, the somewhat modest suggestion in Annex II would seem to reflect Norway's mixed experience from the North Sea. The advantage seen with a redetermination mechanism in the case of Frigg was that it allowed investments to start before apportionment of resources was settled. However, given the problems and costs incurred with redetermination on Statfjord, it seems unlikely that development would start in the Barents Sea before a high level of consensus is reached on the resource base and its apportionment.

In the Barents Treaty, in contrast to the GKZ recommendations, arbitration in the case of disagreement is binding. Moreover, if disagreement concerns apportionment of the deposit, an independent expert shall be appointed by the parties. His decision is binding. Such a procedure will limit the potential for one party to use apportionment discussions to slow down development.

The Treaty provides for the establishment of a "Joint Commission for consultations between the Parties on issues pertaining to any planned or existing unitized hydrocarbon deposits." This is clearly intended as an inter-governmental body for each field development, but with no direct authority in the direct conduct of 
operations. Still, it appears to cover part of the role of the special organ proposed in the GKZ recommendations.

\section{Norwegian and Russian Approaches: Overlaps or Inconsistencies?}

As no cross-border fields have yet been discovered, and talks between Norwegian and Russian authorities are still at an early stage, we can only hypothesize about how the parties might approach implementation of the Barents Treaty if a discovery is made.

The Barents Treaty's annex on transboundary hydrocarbon deposits largely reflects Norway's management of cross-border fields with the UK for more than 40 years. But this does not mean unitization is seen as unproblematic, from a Norwegian point of view. Despite the apparent cultural and institutional closeness between Norway and the UK, implementing the Norway-UK unitization agreements has not been without friction. The tendency to politicize decisions on resource distribution-first with the Frigg field, and then later Statfjord (Brent)—probably led to the decision to leave it to the companies to determine resource shares, limiting governmental involvement, when the Framework Agreement between Norway and the UK was signed in 2005. In the Barents Treaty, however, initial determination and apportioning of reserves are placed on the government level, in the unitization agreement. This may be interpreted as recognition of the more state-centered approach typical of Russian practice.

On the other hand, some lessons learned from the North Sea seem to have found their way into the Barents Treaty. In contrast to the Statfjord Agreement, which included a scheduled redetermination processes, in the Barents Treaty both sides must agree before such a process can be launched. Of course, in the face of great resource uncertainty, the parties might want to include a unilateral redetermination clause when the unitization agreement is negotiated. But as of today, each side has the option of avoiding redetermination. This must be seen against the backdrop of the high costs of redetermination experienced with Frigg and Statfjord.

While the Barents Treaty text clearly reflects the Norwegian way of managing offshore fields, it does not rule out the Russian approach, which is quite different. In the Russian context, trans-border fields have been managed by joint venture companies, special organizations set up with the participation of involved license holders. The Norwegian approach has been to appoint one of the license holding companies as operator. Further, the general understanding in Norway is that JV companies are difficult to organize and involve high transaction costs, since it means bringing together people, technology and procedures from two or more organizations in a new company.

One reason why the Russian side might have a preference for the joint venture company model is that such a structure might be seen as a vehicle for the transfer of technology and know-how between western and Russian companies. However, such objectives may also be met by obliging the operator to include Russian personnel in 


\section{Daniel Fjartoft et al.}

the project organization, without reneging on the principal features of the Norwegian operator model.

The term 'operator' in the Barents Treaty is in itself open to various interpretations and may become a matter for discussion. ${ }^{79}$ Actual arrangements in the Caspian Sea differ even further from the Norwegian unitization experience, although these arrangements imply developing each involved field as one unit.

The Barents Treaty obliges the parties to follow a certain procedure for unitization. However, if both agree, they may decide to find other solutions when they negotiate a unification agreement for a given trans-border deposit. This could be relevant if, for instance, a very large share of a transboundary field is located on one side of the border. According to the approach suggested in the Treaty, unitization will undoubtedly entail significant transaction costs, so it might make commercial sense for the party with the smaller share of the resources to sell its share at a fixed price or according to some formula, and not take part in developing the field. Another possibility would be a model resembling Russia's approach in the Caspian Sea, where rights to resources in known structures straddling the median line border were distributed among the parties as part of the delimitation treaty, but where each party was given a 25-50 percent stake in projects that would end up on the other side of the border. The Norway-Iceland agreement also has some similarities, defining interests in a joint development zone.

However, given the possibility of a more accurate division of resources, as seen in the North Sea, such crude arrangements as those employed in the Caspian would likely appear as a step backwards, from a Norwegian perspective. The arrangement with Iceland came about in response to specific circumstances and Norway made important concessions. ${ }^{80}$ The situation between Norway and Russia is very different, and the agreement with Iceland is probably not seen as relevant by the Norwegian authorities.

Nevertheless, fixing the distribution of resources at an early stage might be practical, even for larger fields. In hindsight, we see that the outcome of the early Frigg negotiations could just as well have been that the parties had agreed upon fixed shares in the field rather than opting for the redetermination mechanism. Given Russian practices for "sealing the deal," similar proposals might be expected concerning the Barents Sea, at an early stage in exploration.

If we compare Norwegian and Russian project organization, Norwegian license committees appear to be a simpler solution than the joint venture companies that have been the dominant model for inter-company cooperation in Russia. As Statoil's agreements with Rosneft from 2012 show, even at a very early stage the project was organized into a separate company with its own staff, office, and other amenities. ${ }^{81}$ The Shtokman project, which involved establishing a special purpose company, demonstrated how expensive setting up a joint venture that ends in nothing can be. ${ }^{82}$

Norwegian deal-making gives the impression of tediousness and complexity, whereas Russia has demonstrated a preference for simplicity in contractual relations. However, such simplicity has not always been advantageous for practical project 
implementation. Stumbling blocks are swift to appear once the ink has dried on government protocols.

Problems may arise not only on the inter-state level. Development of the Tsentralnoe field in the Caspian Sea missed out on one high oil-price cycle because the Russian government was slow in issuing a license to Lukoil. First, the company was barred from getting a production license in 2008; then the process was kept in limbo until 2015-by which time prices had fallen again. In the Barents Sea, however, matters seem simpler. State dominated Rosneft is the license holder on the Russian side and should be a safeguard against institutional hitches. Still, problems may emerge if a gas discovery is made. For years, Rosneft has battled with Gazprom for the right to export gas, and has so far received only limited rights to export LNG. ${ }^{83}$

In the event of a gas discovery, Norway and Russia would have to agree on resource evacuation and possibly a marketing strategy-matters of obvious strategic significance. Such situations emerged during the initial discussions on the Frigg field and again in connection with the Caspian Sea. The Barents Treaty offers no specific provisions in this regard. Negotiations might prove complicated, as the companies' commercial considerations interact with national strategic priorities. Obviously, it might be that neither side finds a gas development sufficiently interesting.

In any case, the relationship and division of roles between companies and the authorities differ in the Norwegian and the Russian oil industries. In the Barents Sea, the parties have yet to explore and agree on organizational models for joint activities that can be compatible with the respective institutional environments. For companies holding licenses on either side of the border this amounts to major uncertainties concerning timing, shape and ultimately the profitability of development. Such considerations could make them reluctant to invest in exploration in the first place.

\section{Concluding Reflections}

This study has examined Norwegian and Russian experiences from managing oil and gas fields that cross license borders, as well as borders with neighboring countries, because we believe this is relevant for implementation of the Barents Treaty. Both parties will, consciously or subconsciously, expect unitization to take a form already familiar to them, letting prior experiences shape their approaches to new challenges.

Russian recommendations for cross-border fields claim to build on the international concept of unitization. However, Russian ideas about unitization differ from the way Norway has unitized fields with neighboring countries, and between licenses on the Norwegian continental shelf.

Our analysis has found objective differences between Norwegian and Russian legislation and practice, but it has also found that the underlying principles and thinking of Norway and Russia have much in common. It seems safe to conclude that there is agreement on the primary purpose and advantage of unitization, namely developing a cross-boundary deposit as one unit. When it comes to more secondary issues, the 
approaches of the two countries are different: apportionment of resources between the parties has been carried out differently, and the organization of joint activities also clearly differs.

It seems likely that, in the event of cross-border discoveries, both parties will enter negotiations in the belief that their own understanding of unitization reflects the true or most workable realization of the concept, expecting the other party to share their view, under the assumption that there is only one correct, true approach. Discussion is likely to arise around the practicalities of implementing field unitization. The differences here are not insurmountable, although arriving at a joint understanding will probably take time. Ultimately, much will depend on both parties' interest in developing transboundary fields.

\section{ACKNOWLEDGMENTS}

This article is a product of the research project Mechanisms for Russian-Norwegian Cross-border Petroleum Cooperation in the Arctic, financed by the NORRUSS program of the Research Council of Norway, grant no. 2436303, and the Russian Foundation for Basic Research (RFBR), project No. 15-27-24002. An overview of issues related to trans-boundary fields was provided in A. Cherepovitsyn, N. Smirnova and A. Moe: "Development of Transboundary Hydrocarbon Fields: Legal and Economic Aspects," Indian fournal of Science and Technology, 9 (2016): 1-10. A companion article by Irina Fodchenko: "A Gold Line? Legal Aspects of the Russian-Norwegian Model for Cross-Border Unitisation in the Barents Sea and Arctic Ocean" forthcoming in Ocean Development $\mathcal{E}$ International Law, 49, No. 4 (2018) analyses the relationship between unitization and the domestic legal frameworks in Russia and Norway. The authors are grateful to Irina Fodchenko and two anonymous reviewers for valuable comments, to Maryam Sugaipova for editorial assistance and to Susan Høivik for language editing.

\section{NOTES}

1. Arild Moe, "Russian and Norwegian Petroleum Strategies in the Barents Sea," Arctic Review on Law and Politics, 1 (2010): 225-48.

2. Arild Moe, Daniel Fjærtoft and Indra Øverland, "Space and Timing: Why Was the Barents Sea Delimitation Dispute Resolved in 2010?” Polar Geography 34 (2011): 145-62.

3. Anatoli Bourmistrov et al. (eds.), International Arctic Petroleum Cooperation - Barents Sea Scenarios (Abingdon, UK: Routledge, 2015).

4. Norwegian Government, "Treaty between the Kingdom of Norway and the Russian Federation,” https://www.regjeringen.no/globalassets/upload/ud/vedlegg/folkerett/avtale_engelsk. pdf

5. Nigel Bankes, "The Regime for Transboundary Hydrocarbon Deposits in the Maritime Delimitation Treaties and Other Related Agreements of Arctic Coastal States," Ocean Development E International Law, 47 (2016): 141-164.

6. Tore Henriksen and Geir Ulfstein, "Maritime Delimitation in the Arctic: The Barents Sea Treaty," Ocean Development E International Law, 42 (2011): 1-21. 
7. Irina Fodchenko, "A Gold Line? Legal Aspects of the Russian-Norwegian Model for Cross-Border Unitization in the Barents Sea and Arctic Ocean," forthcoming in Ocean Develop E International Law, 49, No. 4 (2018).

8. Gunther K. Stahl et al., "Sociocultural Integration in Mergers and Acquisitions: Unresolved Paradoxes and Directions for Future Research," International Business Review 55 (2013): 333-57.

9. Daniel Kahneman, Thinking, Fast and Slow (New York: Farrar, Straus and Giroux, 2011).

10. Vasco Becker-Weinberg, Foint Development of Hydrocarbon Deposits in the Law of the Sea (Heidelberg: Springer, 2014).

11. Jacqueline Lang Weaver and David F. Asmus, "Unitizing Oil and Gas Fields Around the World: A Comparative Analysis of National Laws and Private Contracts," Houston fournal of International Law, 28 (2006).

12. Ross H. Pifer, "The Rule of Capture in Pennsylvania Oil and Gas Law," Agricultural Law Resource and Reference Center, Penn State University (2009).

13. U.S. Government Publishing Office, Public Law 91-158. December 24, 1969. https://www. gpo.gov/fdsys/pkg/STATUTE-83/pdf/STATUTE-83-Pg436.pdf

14. Howard R. Williams and Charles J. Meyers, "The Effect of Pooling and Unitization upon Oil and Gas Leases", California Law Review 45: 411-49 (1957).

15. Terence Daintith, Finders Keepers? How the Law of Capture Shaped the World Oil Industry (Washington, D.C.: RFF Press, 2010).

16. Weaver and Asmus, "Unitizing Oil and Gas Fields around the World".

17. Rainer Lagoni, "Oil and Gas Deposits Across National Frontiers," The American fournal of International Law 7 (1979): 215-43.

18. Ana E. Bastida et al., "Cross-Border Unitization and Joint Development Agreements: An International Law Perspective," Houston fournal of International Law 29 (2007): 355-422..

19. William T. Onorato, "Apportionment of an International Common Petroleum Deposits," International and Comparative Law Quarterly 26 (1977).

20. Peter D Cameron, “The Rules of Engagement: Developing Cross-Border Petroleum Deposits in the North Sea and the Caribbean," International and Comparative Law Quarterly, 55 (2006): 559-586.

21. Weaver and Asmus, "Unitizing Oil and Gas Fields around the World".

22. Anozie Ikechukwu Awambu, "Unitization of Contract Areas: Is it an Obligation Defeating the Stability of International Petroleum Agreements?," CAR CEPMLP Annual Review (2008).

23. Norwegian Petroleum Directorate, Fact Pages (2015) http://factpages.npd.no/FactPages/default.aspx?nav1 $=$ field\&nav2 $=$ PageViewpercent 7 cAll\&nav3 $=3437650$

24. Rolf Tamnes, Oljealder (Oil age), (Oslo: Universitetsforlaget, 1997): 302-309.

25. Pavel Prokhorov, “Делимитация российско-норвежской морской границы: состояние и перспективы (Delimitation of the Russian-Norwegian maritime border: status and perspectives)," St. Petersburge: Electronic Library of the Museum of anthropology and ethnography in the name Peter the Great (Kunstkamera), Russian Academy of Sciences (2008).

26. "Agreement between the Government of the United Kingdom of Great Britain and Northern Ireland and the Government of the Kingdom of Norway relating to the delimitation of the continental shelf between the two countries," March 10, 1965. UN, Delimitation Treaties InfoBase. http://www.un.org/depts/los/LEGISLATIONANDTREATIES/PDFFILES/ TREATIES/GBR-NOR1965CS.PDF

27. United Nations, "Handbook on the Delimitation of Maritime Boundaries," (2000) http://dx.doi. org/10.18356/cc72cd88-en

28. "Agreement between the Government of the United Kingdom of Great Britain and Northern Ireland and the Government of the Kingdom of Norway...." 


\section{Daniel Fjartoft et al.}

29. United Kingdom of Great Britain and Northern Ireland and Norway, "Agreement relating to the exploitation of the Frigg Field Reservoir and the transmission of gas therefrom to the United Kingdom," signed at London on May 10, 1976. UN, Treaties. Registered July 20, 1978. https:// treaties.un.org/doc/Publication/UNTS/Volume\%201098/volume-1098-I-16878-English.pdf.

30. The Petroleum Act and the licensing system. http://www.norskpetroleum.no/en/framework/ the-petroleum-act-and-the-licensing-system/

31. Greg W. Gordon, "Production Licensing on the UK Continental Shelf: Ministerial Powers and Controls", LSU fournal of Energy Law and Resources, 4 (2015): 75-95.

32. Derek C. Smith, "Norway-United Kingdom," in International Maritime Boundaries Vol. V, eds. David A. Colson and Robert W. Smith (Leiden/Boston: Martinus Nijhoff Publishers, 2005): 3945-3948.

33. Gunnar Nerheim, "En prøvesten på petroleumshushold og unitisering (A touchstone for petroleum housekeeping and unitization)," Norwegian Oil Museum Yearbook (1991).

34. Ibid., 52-53.

35. Ibid.

36. Ian Gault, "The Frigg gas field - exploitation of an international cross-boundary petroleum field," Marine Policy 3 (1979): 302-311.

37. Nerheim, "En prøvesten på petroleumshushold og unitisering (A touchstone for petroleum housekeeping and unitization)," 64-65.

38. Government of the United Kingdom, Statfjord Agreement. Oslo, October 16, 1979. http:// treaties.fco.gov.uk/docs/pdf/1981/TS0044.pdf

39. Government of the United Kingdom, Murchison Field Agreement (Supplementary to the Statfjord Agreement), Oslo, June 22, 1983. http://treaties.fco.gov.uk/docs/fullnames/ pdf/1983/TS0071 percent20(1983)percent20CMND-9083percent201983percent2022percent20JUN,percent20OSLOpercent3Bpercent20SECONDpercent20AGREEMENTpercent20SUPPLEMENTARYpercent20TOpercent20AGREEMENTpercent20OFpercent2016 percent20OCTpercent201979percent20BETWEENpercent20GOVpercent20OFpercent20UK,percent20NIpercent20\&percent20NORWAY.pdf

40. Norwegian Petroleum Directorate, Fact Book. (2014). http://www.npd.no/Global/Norsk/3Publikasjoner/Faktahefter/Fakta2014/Fakta_2014_NO_nett_.pdf

41. Håkon Lavik, "Statfjordavtaler (Statfjord agreements)," Statfjord kulturminne (2009): 4. http://www.kulturminne-statfjord.no/var/plain_site/storage/original/application/eb86afae $4352461154 d c 465 c 2$ e4833ff.pdf

42. Ibid., $4-5$.

43. Håkon Lavik, "Den siste redetermineringsprosessen 1995-98 (The last redetermination process 1995-98)," Statfjord kulturminne (2010). http://www.kulturminne-statfjord.no/var/ plain_site/storage/original/application/7b7d984b73e7702cbf7ed32ee96bbfa6.pdf

44. Statfjord. http://www.norskpetroleum.no/en/facts/field/statfjord/

45. PILOT and KON-KRAFT, "Unlocking Value Through Closer Relationships," August 2002. https:/www.regjeringen.no/globalassets/upload/kilde/oed/rap/2002/0005/ddd/pdfv/159 318-report_uk-norway_workgroup_-final.pdf

46. Norwegian Government, "Building UK-Norway Cooperation in the North Sea," Oslo, October 2, 2003. https:/www.regjeringen.no/globalassets/upload/kilde/oed/prm/2003/0152/ ddd/pdfv/188407-uk_avtale_2.10.pdf

47. Norwegian Government, "Framework Agreement," Oslo, April 4, 2005. https://www.regjeringen.no/globalassets/upload/kilde/oed/prm/2005/0142/ddd/pdfv/242757-traktat_no_ storbrit_e_april_05.pdf

48. Nigel Bankes, "Recent Framework Agreements for the Recognition and Development of Transboundary Hydrocarbon Resources," The International fournal of Marine and Coastal Law 29 (2014): 666-689. 
Unitization of petroleum fields in the Barents Sea:Towards a common understanding?

49. UN, Delimitation Treaties InfoBase, “Norway - Iceland Treaty 1981.” http://www.un.org/ depts/los/LEGISLATIONANDTREATIES/PDFFILES/TREATIES/ISL-NOR1981CS. PDF

50. Bankes, "The Regime for Transboundary Hydrocarbon Deposits...".

51. "Agreed Minutes between Norway and Iceland," signed November 3, 2008. https://lovdata. no/dokument/TRAKTATEN/traktat/2008-11-03-80

52. JoAndreAakvik, "Norgeblirmed påislandskoljesatsing (Norwayjoins Icelandic oil effort)," $e 24$. no, January 4, 2013. http://e24.no/energi/norge-blir-med-paa-islandsk-oljesatsing/20319804

53. "Første oljeavtale utenlands inngått med Island (First oil agreement abroad signed with Iceland)," Sysla Offshore, January 4, 2003. https://sysla.no/offshore/ foerste_oljeavtale_utenlands_inngaatt_med_island/

54. Hilde Øvrebekk Lewis, "Norge skal samarbeide med Kina om olje på Island (Norway will cooperate with China on oil in Iceland)," Stavanger Aftenblad, November 26, 2013. https://www. aftenbladet.no/aenergi/i/Ommq3/Norge-skal-samarbeide-med-Kina-om-olje-pa-Island

55. Orkustofnun - National Energy Authority, "CNOOC, Eykon and Petoro optimistic on the status and continuation of oil exploration in Iceland," October 7, 2016. http://www.nea.is/ the-national-energy-authority/news/nr/1813

56. Arild Moe and Valery Kryukov, "Oil Exploration in Russia: Prospects for Reforming a Crucial Sector," Eurasian Geography and Economics 51 (2010): 312-29.

57. Maria Selivanova, “Отняв НДПИ, регионам позволят увеличить транспортный налог (Withholding mineral extraction tax, the regions will be allowed to increase transport tax)," $R B K-$ daily August 20, 2009. https://finance.rambler.ru/news/taxes/49963219.html

58. Law of the Russian Federation, 1992. N 2395-1 "О недрах (About underground resources)", including amendments as of 30 September 2017. http://base.garant.ru/10104313/

59. Russian Ministry of Foreign Affairs, “Договор между Российской Федерацией и Литовской Республикой о разграничении исключительной экономической зоны и континентального шельфа в Балтийском Mope (Agreement between the Russian Federation and the Lithuanian Republic on the delimitation of the exclusive economic zone and continental shelf in the Baltic Sea)," Signed October 24, 1997. http://www.mid.ru/foreign_policy/ international_contracts/2_contract/-/storage-viewer/bilateral/page-257/47473

60. Russian Federation, “Соглашение между Российской Федерацией и Республикой Казахстан от 06.07.98 О разграничении дна северной части Каспийского Моря в целях осуществления суверенных прав на недропользование (Agreement between the Russian Federation and the Republic of Kazakhstan of 06.07 .98 on delimitation of the seabed of the northern part of the Caspian Sea for the purpose of the exercise of sovereign rights to subsoil management)," http://www.zakonprost.ru/content/base/48651

61. Robert W. Smith and J. Ashley Roach, "Kazakhstan-Russia" in International Maritime Boundaries Vol. V, eds. David A. Colson and Robert W. Smith (Leiden/Boston: Martinus Nijhoff Publishers, 2005): 4013-4020. The volume also contains an English translation of the agreement and the protocol: 4022-4041.

62. Russian Ministry of Foreign Affairs, “Протокол к соглашению между Российской Федерацией и Республикой Казахстан о разграничении дна северной части Каспийского Моря в целях осуществления суверенных прав на недропользование от 6 июля 1998 года (Protocol to the Agreement between the Russian Federation and the Republic of Kazakhstan on the delimitation of the seabed of the northern part of the Caspian Sea for the purpose of the exercise of sovereign rights to subsoil management of 6 July 1998)," March 13, 2002. http:// www.mid.ru/foreign_policy/international_contracts/2_contract/-/storage-viewer/bilateral/ page- $176 / 46360$

63. Ibid.

64. Ibid. 


\section{Daniel Fjartoft et al.}

65. “Алексей Миллер и Вагит Алекперов подписали учредительный договор о создании совместного предприятия «ЦентрКаспнефтегаз» (Aleksey Miller and Vagit Alekperov signed founding agreement for establishment of the joint venture TsentrKaspneftegaz)," Gazprom Press release, July 1, 2003. http://www.gazprom.ru/press/news/2003/july/article54504/

66. “СП «Газпрома” и «Лукойла» получило лицензию на каспийское месторождение (JV of Gazprom and Lukoil received license for Caspian field)," Lenta Business, November 14, 2016. https:/lenta.ru/news/2016/08/15/gazprom/

67. “«Лукойл» хочет продавать газ в Китай (Lukoil wants to sell gas to China),” Vedomosti, October 29, 2017. https://www.vedomosti.ru/business/articles/2017/10/30/739784-lukoil-ga z-kitai

68. Ivan Zabludnev, “Хвалынское, Центральное (Khvalinskoe, Tsentralnoe),” Oil \& Gas Journal Russia, June 2014.

69. “«Лукойл» хочет продавать газ в Китай (Lukoil wants to sell gas to China)”

70. “Месторождение «Имашевское» (Imashevskoe field),” Книга нефти: нефтегазовая отрасль в России (The Oil Book: Oil and Gas Industry in Russia), 2014. http://kniganefti.ru/field. asp?field $=312$

71. KazRosGaz, “О компании: История (About the Company: History),” http://kazrosgas.org/ rus/o-kompanii/istoriya/

72. “Роснедра нашли способ выдать Газпрому и КМГ поисковую лицензию на Имашевский участок (Rosnedra found a way to give Gazprom and KMG an exploration license for the Imashevskoe field)," National Business, May 5, 2016. http://nb.kz/15134/

73. “Минприроды рассмотрит альтернативные формы предоставления Имашевского месторождения (The Ministry of Natural Resources will consider alternative forms of providing the Imashevskoye field)," Neft Rossii, October 27, 2016. http://www.oilru.com/ news $/ 539458$

74. “«Роснефть» и Казахстан подписали соглашение о совместной разработке Курмангазы (Rosneft and Kazakhstan signed agreement on joint development of Kurmangazy)," Vedomosti, July 6, 2005. https://www.vedomosti.ru/library/news/2005/07/06/ rosneft-i-kazahstan-podpisali-soglashenie-o-sovmestnoj-razrabotke-kurmangazy

75. The State Commission for Mineral Reserves (GKZ), "Рекомендации по подсчету запасов по сопредельным и трансграничным участкам недр (Recommendations for assessment of reserves in adjoining and transboundary subsoil plots)," December 12, 2007. http://www. gkz-rf.ru/uglevodorodnoe-syre

76. Fodchenko, "A Gold Line?”

77. Russian Federation and Kingdom of Norway, "Agreement between the Russian Federation and the Kingdom of Norway on the Maritime Delimitation in the Varangerfjord Area, signed July 11, 2007," UN Law of the Sea Bulletin, 67 (2008). http://www.un.org/Depts/los/doalos_publications/LOSBulletins/bulletinpdf/bulletin67e.pdf

78. Agreement for petroleum activities and model production licenses. Last updated September 6, 2017. https://www.regjeringen.no/en/find-document/dep/OED/Laws-and-rules-2/Rules/ konsesjonsverk/id748087/

79. See Fodchenko, "A Gold Line?" for further elaboration.

80. Bankes, "The Regime for Transboundary Hydrocarbon Deposits...".

81. "Rosneft and Statoil sign shareholder agreements for Russian offshore exploration joint ventures," Rosneft press release August 30, 2012. https://www.rosneft.com/press/releases/ item/114451/

82. James Henderson and Arild Moe, "Gazprom's LNG offensive: a demonstration of monopoly strength or impetus for Russian gas sector reform," Post-Communist Economies 28 (2016): 281-99.

83. Ibid. 